\title{
Seasonal Variations in Abundance and Distribution of Pollution Indicator Bacteria of an Eastern Himalayan Lake of India
}

\author{
Debashri Mondal \\ Department of Zoology, Raiganj University, Raiganj, Uttar Dinajpur, West Bengal, India
}

Received March 21, 2020; Revised May 30, 2020; Accepted June 4, 2020

\section{Cite This Paper in the following Citation Styles}

(a): [1] Debashri Mondal, "Seasonal Variations in Abundance and Distribution of Pollution Indicator Bacteria of an Eastern Himalayan Lake of India," Advances in Zoology and Botany, Vol. 8, No. 5, pp. 383 - 391, 2020. DOI: 10.13189/azb.2020.080502.

(b): Debashri Mondal (2020). Seasonal Variations in Abundance and Distribution of Pollution Indicator Bacteria of an Eastern Himalayan Lake of India. Advances in Zoology and Botany, 8(5), 383 - 391. DOI: 10.13189/azb.2020.080502.

Copyright $\odot 2020$ by authors, all rights reserved. Authors agree that this article remains permanently open access under the terms of the Creative Commons Attribution License 4.0 International License

\begin{abstract}
Mirik Lake" of Darjeeling Himalaya is an artificial reservoir of Mirik, the famous hill resort in the Kurseang subdivision of Darjeeling District, West Bengal, India at an altitude of 1767 meters above mean sea level. The Mirik Lake which was constructed in 1979 primarily for the facilitation of commercial tourism in Darjeeling is fed by both perennial streams and rain water. The Lake is used extensively for different recreational activities as well as supplies drinking water to local people of the Mirik Town. To investigate the seasonal variation of fecal coliform, total coliform and heterotrophic bacterial density of the Mirik Lake, surface water samples from seven sampling points of the Lake were collected on a monthly basis for two years. Seasonally, the highest MPN values of fecal coliform $(29000 / 100 \mathrm{~mL})$, total coliform $(88667 / 100$ $\mathrm{mL})$ and heterotrophic bacteria $(116667 / \mathrm{mL})$ were recorded from Site 1 during monsoon season of the second year of the study period and the lowest values were recorded during winter season. The fecal coliform density of Site 1 and Site 2 were always higher than other sites might be due to the fecal contamination in these two sites where drains from houses and hotels directly discharge waste water into the lake. Both the total coliform and heterotrophic bacterial density exhibited positive and significant correlation with fecal coliform at all the sites. It was observed that fecal coliform, total coliform and heterotrophic bacteria were substantially high and much beyond the permissible limit of ISI and WHO. Result suggests that sampling station S-1, S-2 and S-6 found to be
\end{abstract}

more disturbed than the others and special attention is needed to avoid health hazards. For the improvement of the quality of Lake water, the sewage must be treated before disposal into the lake.

Keywords Mirik Lake, Fecal Coliform, Total Coliform, Heterotrophic Bacteria

\section{Introduction}

Water receives its bacterial content from air, soil, sewage, organic wastes, dead plants and animals etc. Most of the bacteria find conditions unfavorable and soon die. Those species which survive and are constantly present constitute the natural flora of water. To assess the quality of water in terms of pathogenic and parasite organisms indicating a health risk for the human population, the use of an indicator system is considered to be indispensable, due to the vast variety of these organisms. The coliform bacteria, especially the thermo-tolerant types are considered to be a convenient indicator for the exposure of a water body to the faeces of warm blooded organisms, including man. Since human water- borne diseases are mainly transferred by exposure to fecal matter, the health risk can be associated by measuring the presence of these bacteria [1] The occurrence of coliform group, total coliform, and fecal coliform has been used as principal 
ecological indicators of water pollution [2, 3, 4, 5]. For many years, the fecal coliform Eschericia coli have been used as an indicator of human enteric pathogens [6]. However, it is now well established that E. coli is not limited to humans but also exists in the intestines of many other warm blooded animals [7]. The heterotrophic plate counts (HPC), expressed as colony-forming units (CFU), became one of the standard techniques for microbial water quality testing [8]. On the other hand, HPC (heterotrophic bacterial count) values provide density of aerobic and facultative bacteria in water sample, which can grow at $37^{\circ} \mathrm{C}$. The HPC values are useful in warning about excessive microbial growth in any water and also in judging the efficiency of water and waste water treatment in removing microorganisms [9].

Pant et al. [10] reported presence of Escherichia coli at a concentration of $11 \times 10^{5} / 100 \mathrm{~mL}$ of water in Lake Nainital which attributed to pollution due to release of domestic effluents containing fecal matter of human and non- human origin. Coliform organisms, while relatively harmless themselves, are most invariably present in waters, they live longer than the disease producing organisms. Consequently, these organisms have been considered to be the prime indicators of water quality and potential health hazards [11]. Prakasam and Joseph [12] studied the pollution of Sastham Cotta Lake, Kerala due to presence of coliform bacteria, especially fecal ones. Fokmare et al. [13] studied the bacteriological status of drinking water in Akola city of Maharashtra and recorded higher amount of bacteria in ground water (untreated) than in tap water (treated). Bhadra et al. [14] investigated the density of heterotrophic, total and fecal coloform and fecal streptococcai bacteria in the river Torsa, North Bengal and found highest and lowest total and fecal coliform count respectively in the month of March and January. Isobe et al. [15] studied the effect of environmental factors on the relationship between concentration of coprostanol and fecal indicator bacteria in tropical (Mekong Delta, Vietnam) and temperate (Tokyo, Japan) freshwaters. Karagul et al. [16] investigated the fecal coliform load in Buyuk Melen river basin (Duzce, Turkey) and found highest fecal coliform in spring which could be due to increase in water temperature and suspended sediment at that period. The actinomycetes population of Rankala and Kalamba lakes of Maharashtra was studied by Jadhav and Desmukh [17]. Usha et al. [18] counted the bacterial density of water of Perumal Lake, Tamilnadu and recorded highest plate count during the rainy seasons. Ksoll et al. [19] studied the presence and sources of fecal coliform bacteria in Epilithic periphyton communities of Lake Superior. They found that fecal coliform densities increased upto 4 orders of magnitude in early summer, reached peaks by late July, and decreased during autumn.

Radha Krishnan et al. [20] analyzed bacterial parameters like standard plate count, total coliform count, fecal coliform count and fecal streptococci count of drinking, borewell and sewage water in three different places of Sivakasi. Omezuruike et al. [21] studied the microbiological and physico chemical analysis of different water samples used for domestic purposes in Abeokuta and Ojota of Lagos State, Nigeria. Rodrigues et al. [22] studied the long-term variations in abundance and distribution of sewage pollution indicator and human pathogenic bacteria along the central west coast of India. Seasonal dynamics of bacterial community structure and composition in cold and hot drinking water derived from surface water reservoirs was studied by Henne et al. [23]. Patel et al. [24] investigated the response of bacterial community structure to seasonal fluctuation and anthropogenic pollution on coastal water of Alang-Sosiya ship breaking yard, Bhavnagar, India. Fadaei, [25] compared the bacteriological quality of drinking water for the rural of Hooreh and Arjnk, Iran. The microbiological characteristics of water along Gurupur estuary Mangalore, Karnataka were analysed by Kademane et al. [26]. On the other hand, Haque et al. [27] assessed the bacterial parameters such as total heterotrophic bacteria, total coliform, fecal coliform and Vibrio cholera from four different study sites of Padma River at Rajshahi, Bangladesh.

Though a vast number of bacterial investigations have been done throughout India, bacteriological works of the water bodies of Darjeeling Hills is very scanty [28]. Till date no work has been reported on the seasonal variation of bacterial load of Mirik Lake of Darjeeling Himalaya. Therefore, the present study was aimed to determine the bacterial load of the Mirik Lake in different seasons.

\section{Materials and Methods}

\subsection{Study Site}

Mirik is one of the famous hill resorts in the Darjeeling Himalaya at an altitude of 1767 meters. It extends between $26^{\circ} 53^{\prime} \mathrm{N}$ and $88^{\circ} 10^{\prime} \mathrm{E}$ and covers an area of 135.9 ha. "Sumendu Lake" or "Mirik Lake" is an artificial reservoir of Mirik Town. It was constructed in 1979 under "Mirik Tourist Project" for the facilitation of commercial tourism. The area, under jurisdiction of Mirik Municipal Corporation, is overall controlled by Darjeeling Gorkha Hill Council (DGHC). This lake has been included under National Lake Conservation Programme, formulated by the Ministry of Environment and Forests, Government of India [29, 30, 31 and 32].

\subsection{Area and Surroundings of Mirik Lake}

The total lake area is about 16.19 ha with approximate length of $1.25 \mathrm{~km}$ and the peripheral road is about $3.5 \mathrm{~km}$. The arch-type over bridge across the lake is $24.38 \mathrm{~m}$ long $[29,30,31$, and 32]. Initially maximum depth of the lake was $7.92 \mathrm{~m}$ while minimum was $1.83 \mathrm{~m}$ [33]. While eastern 
bank of the lake is flat at ground level, the western bank, having hill slopes, is covered by a rich forest of about ten thousand Cryptomaria japonica trees. The lake is fed by both perennial streams and rainwater. Since the lake is situated in a valley encircled by hill ridges with extensive natural drainage network, it receives wastewater from human settlements through numerous inlets. There is one out-fall point through which the spillover water of the lake is discharged into the river Mechi, situated to the Western side of the lake. The catchment area consists of residential areas, vacant lands and commercial centers comprising of hotels, restaurants and other shops. Mirik Lake and its surroundings, as a whole, contain multifarious recreational features like boating, jogging, organizing fair, picnic and many others. This is the most beautiful lake of Darjeeling district where visitors come from different parts of the world. Besides attracting tourists, the lake water also serves as a major source of drinking water to the local people.

\subsection{Sampling Sites}

Seasonal variation of bacterial water quality of Mirik Lake water was studied for two years. Considering length of the lake as well as point and non-point sources of pollution, seven sampling sites were identified in the Lake (Figure 1). The water samples were collected every month at regular intervals from these locations with the help of paddle-boat. For seasonal interpretations, the periods March to June, July to October and November to February were considered as summer, monsoon and winter respectively. The brief descriptions of the sites are represented in Table 1.

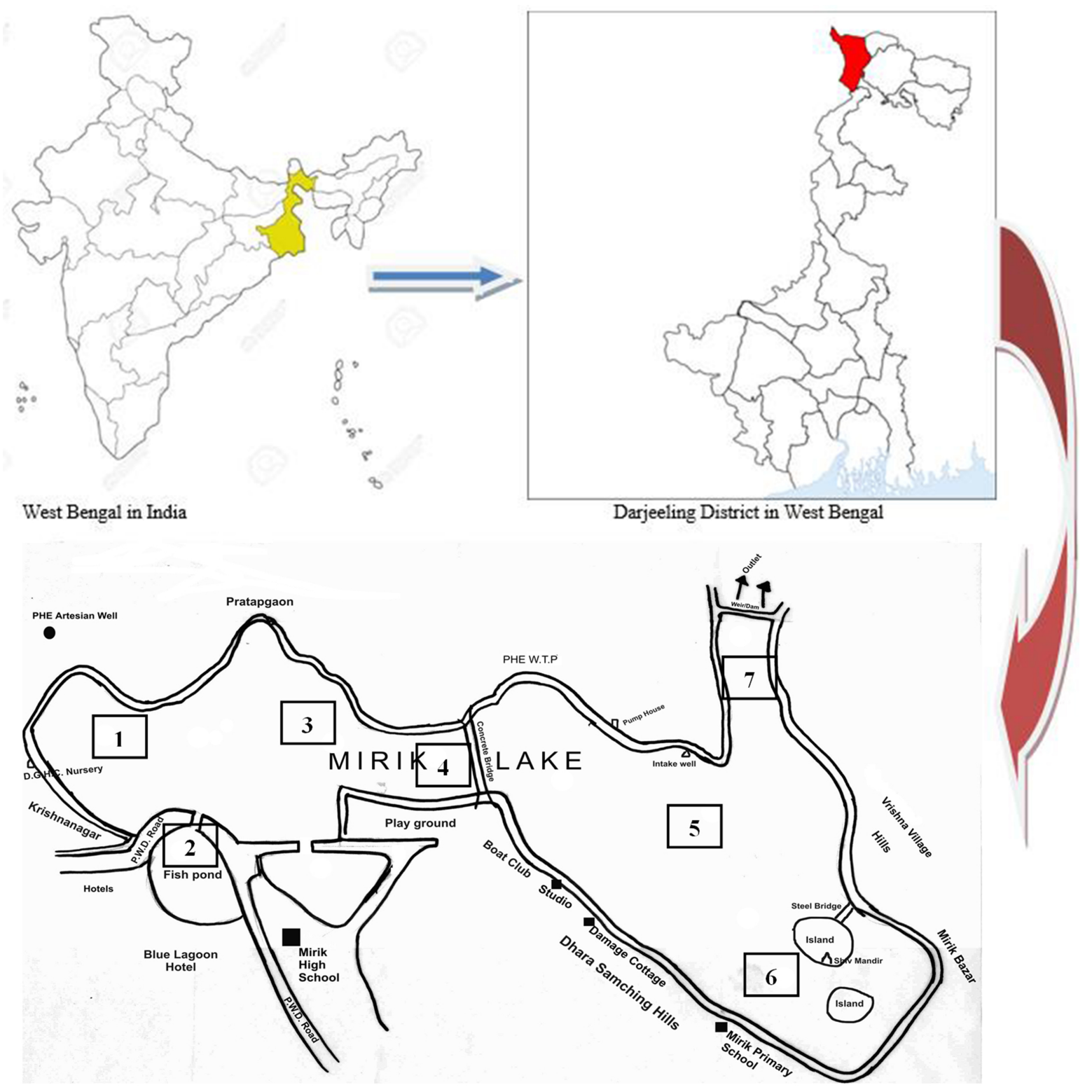

Figure 1. Location of sampling sites at Mirik Lake, Darjeeling, West Bengal, India 
Table 1. Description of different sampling sites of Mirik Lake

\begin{tabular}{|c|c|c|c|}
\hline $\begin{array}{c}\text { Sampling } \\
\text { Sites }\end{array}$ & Latitude- N & Longitude-E & \multicolumn{1}{c|}{ Characteristics } \\
\hline Site 1 & $26053^{\prime} 08.49^{\prime \prime} \mathrm{N}$ & $88011^{\prime} 08.32^{\prime \prime} \mathrm{E}$ & $\begin{array}{l}\text { It is 250 m away from DGHC Nursery toward North West. Joining of wastes from } \\
\text { hotels and residential area and car washing takes place at this site. }\end{array}$ \\
\hline Site 2 & $26053^{\prime} 16.80^{\prime \prime} \mathrm{N}$ & $88011^{\prime} 14.95^{\prime \prime} \mathrm{E}$ & $\begin{array}{l}\text { This is the feeding ground of colourful fishes which accumulate here to eat the food } \\
\text { particles thrown by the visitors. Waste materials from hotels and residential area } \\
\text { also joining into the lake at this site. }\end{array}$ \\
\hline Site 3 & $26053^{\prime} .20^{\prime \prime} \mathrm{N}$ & $88011^{\prime} 01^{\prime \prime} \mathrm{E}$ & $\begin{array}{l}\text { It is located at 100 m away from the concrete bridge of the lake towards South East } \\
\text { near the children park area. Human activity is comparatively lesser at this site. }\end{array}$ \\
\hline Site 4 & $26053^{\prime} .017^{\prime \prime} \mathrm{N}$ & $88010^{\prime} .927 "$ & $\begin{array}{l}\text { It is located at the centre of concrete bridge over the lake. Some amount of surface } \\
\text { runoff joins here. }\end{array}$ \\
\hline Site 5 & $26053^{\prime} 38.40^{\prime \prime} \mathrm{N}$ & $88010^{\prime} 55.11^{\prime \prime} \mathrm{E}$ & $\begin{array}{l}\text { It is situated at 90 m away from the water intake point towards North East. This } \\
\text { water intake well is used for water treatment plant under PHED having a capacity of } \\
\text { 1MGD (Million Gallon per Day) to cater the water supply for the people of Mirik } \\
\text { Municipality area. Anthropogenic activities are comparatively lesser at this site. }\end{array}$ \\
\hline Site 6 & $26053^{\prime} 27.99^{\prime \prime} \mathrm{N}$ & $88010^{\prime} 56.53^{\prime \prime} \mathrm{E}$ & $\begin{array}{l}\text { Located between Shibmandir and an island where waste water coming mainly from } \\
\text { the Mirik market area. Bathing and washing of clothes takes place at this site. }\end{array}$ \\
\hline Site 7 & $26053^{\prime} 34.53^{\prime \prime} \mathrm{N}$ & $88010^{\prime} 51.89 " \mathrm{E}$ & $\begin{array}{l}\text { It is situated near the outlet of Mirik Lake which is joining to the Mechi River } \\
\text { through weirs. Washing of clothes and bathing also takes place near this site. }\end{array}$ \\
\hline
\end{tabular}

\subsection{Techniques Used for Bacterial Analysis}

Surface water samples were collected in sterilized glass bottles and were transported to the laboratory in ice box.

\section{Determination of coliform bacterial load}

Total coliform load: It was determined following multiple tube fermentation technique and Mac Conkey Broth and Brilliant Green Bile Broth (BGBB) were used for the presumptive and confirmatory tests respectively. The bacterial density was calculated on the basis of positive and negative combination of the tubes using MPN tables [5]. Fecal coliform load: To determine the fecal coliform load one loopful of sample from the positive tubes of presumptive test of total coliform was transferred and incubated in EC Broth. The calculation of MPN of fecal coliform was done in the same manner as in the total coliform [5].

Heterotrophic bacterial load: To determine Heterotrophic bacterial load plate count method was followed using nutrient agar medium following Standard Methods [5].

\section{Data analysis}

Statistical processing of data was done by using EXCEL software. The statistical significance of the correlation between different bacterial parameters was verified by the Pearson correlation analysis test. A p-value of 0.05 indicated a statistically significant difference.

\section{Results and Discussion}

\subsection{Seasonal Variation of Fecal Coliform Bacteria and Its Impact on Water Quality}

Faecal coliform bacteria are the typical genera of the coliform groups. These faecal coliforms are the best indicators of sewage pollution as they originate in the intestinal tract of warm blooded animals and enter the ecosystem in the form of faeces. The monthly data on the number of fecal coliform bacteria of water of seven sampling sites of Mirik Lake of the whole study period are pooled in seasonal values and are shown in the Figure 2. The highest MPN value of fecal coliform bacteria was found in summer $(13500 / 100 \mathrm{~mL})$ from the Site 2 and the lowest value of MPN was recorded in monsoon from Site 5 $(218 / 100 \mathrm{~mL})$ during the first year of study period. The higher fecal coliform density observed during summer from Site 1, Site 2, Site 3, Site 4 and Site 7 and during monsoon from Site 5 and Site 6 (Figure 2). During the second year of study the maximum MPN value was recorded in the Site $1(29000 / 100 \mathrm{~mL})$ during monsoon, while the lowest value was found from the Site 7 (310/100 $\mathrm{mL}$ ) in the winter season. The highest seasonal values suggest higher fecal coliform density during monsoon from Site 1, Site 2, Site 4 and Site 5 and during summer from Site 3, Site 6 and Site 7. Haque et al. [27] also found maximum bacterial density during summer season. The MPN values of fecal coliform in the Mirik Lake were always higher than the Standard limits recommended by the WHO (Table 2). Several studies have reported that the growth and survival of fecal indicator bacteria are susceptible to environmental factors, such as water temperature [34, 35], sunlight [36, 37] and rainfall [38, 39]. The fecal coliform density of Site 1 and Site 2 were always higher than other sites. It may be due to the fecal contamination in these two sites. Drains from houses and hotels directly discharge waste water to the Mirik Lake especially at Site 1 and Site 2 . These results are well compared with Kademane et al. [26] where higher counts of fecal coliforms were observed at the stations that receives sewage effluents. The fecal coliform had positive and significant correlation with total coliform and heterotrophic bacterial density at all the sites (Table 3). 


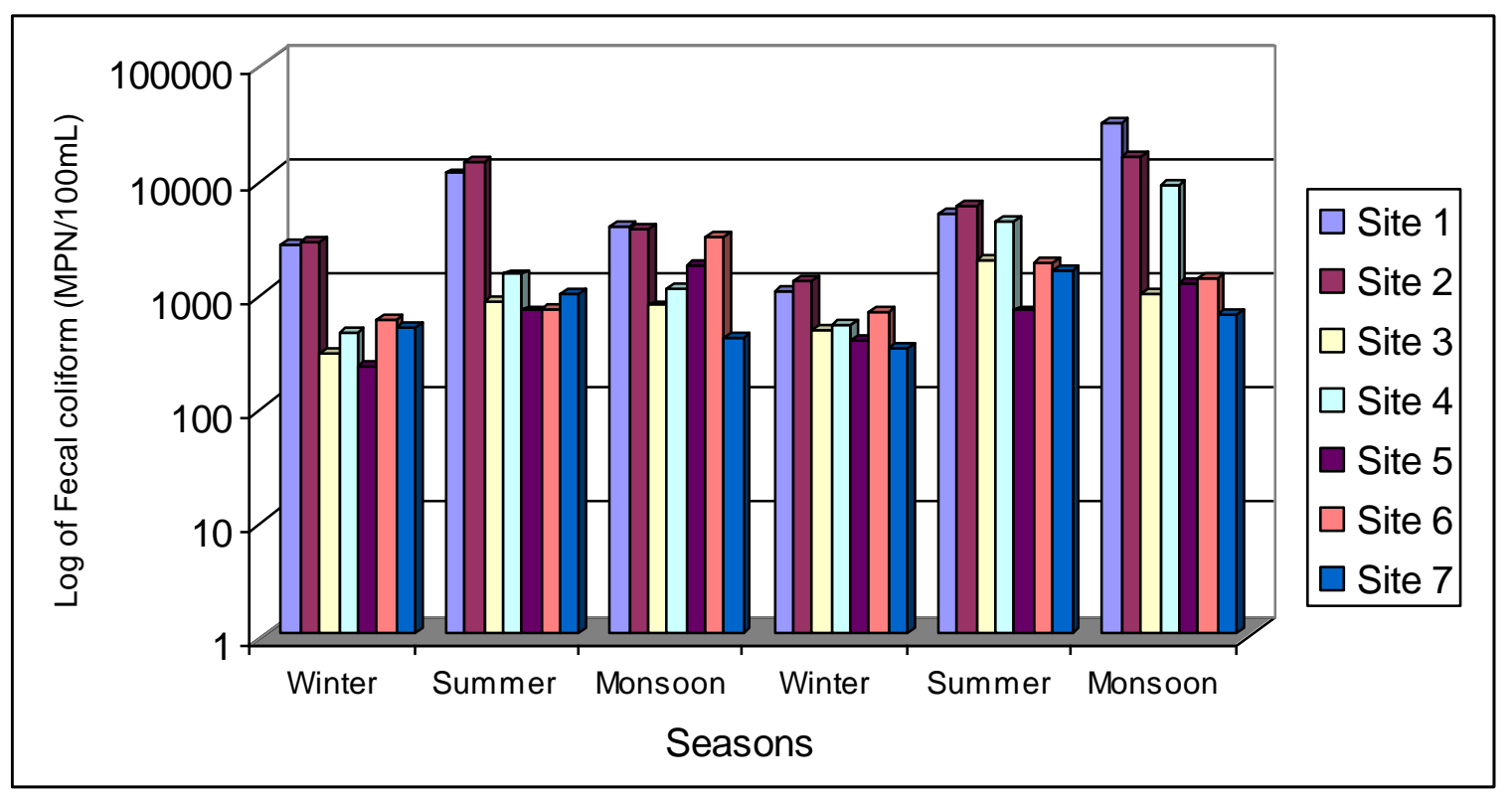

Figure 2. Seasonal variations of Fecal coliform bacteria of surface water from seven sampling sites of Mirik Lake during the whole study period (two years)

Table 2. Different Water Quality Standards

\begin{tabular}{|c|c|c|c|}
\hline Parameters & $\begin{array}{c}\text { WHO Recommendations (Drinking } \\
\text { Water Quality Standards) [40] }\end{array}$ & $\begin{array}{c}\text { WHO recommended microbiological } \\
\text { quality guidelines for wastewater use in } \\
\text { agriculture[40] }\end{array}$ & $\begin{array}{c}\text { Indian Standards for various } \\
\text { surface water quality } \\
\text { Classes*[41] }\end{array}$ \\
\hline \multirow{3}{*}{ Coliforms (MPN/100ml) } & a. 0 & - & - \\
& b. 0,3 & & A- 50 \\
c. 0,3 & d. 10 & & B- 500 \\
Total Coliform (MPN/100ml) & & - & C- 5000 \\
& - & & D- \\
& & & E- \\
\hline Fecal Coliform (cells/litre) & - & $<1000$ & - \\
\hline
\end{tabular}

a-Treated water fed into mains; b-Untreated water fed into mains; c-mains water; d-Non-mains water supply * CPCB classification with respect to Designated Best Use (DBU)

A - Drinking water without conventional treatment but after disinfection. B - Water for outdoor bathing. C - Drinking water with conventional treatment followed by disinfection. D - Water for fish culture and wild life propagation. E - Water for irrigation, industrial cooling and controlled waste disposal. (Unobj = Unobjectionable).

Table 3. Pearson's Coefficient of Correlation for Fecal Coliform, Total Coliform and Heterotrophic Plate Count for two years. N=24, d.f. $=22$

\begin{tabular}{|c|c|c|c|}
\hline Parameters & \multirow{2}{*}{$\begin{array}{l}\text { Fecal Coliform vs } \\
\text { Total Coliform }\end{array}$} & \multirow{2}{*}{$\begin{array}{c}\text { Fecal Coliform } \\
\text { vs } \\
\text { Heterotrophic Plate Count }\end{array}$} & \multirow{2}{*}{$\begin{array}{c}\text { Total Coliform } \\
\text { vs } \\
\text { Heterotrophic Plate Coun }\end{array}$} \\
\hline Sampling Sites & & & \\
\hline Site 1 & $0.8591 * *$ & $0.9053 * *$ & $0.9846^{* *}$ \\
\hline Site 2 & $0.8365^{* *}$ & $0.8455^{* *}$ & $0.9888 * *$ \\
\hline Site 3 & $0.5690 *$ & $0.6359 * *$ & $0.9745 * *$ \\
\hline Site 4 & $0.8225^{* *}$ & $0.8568 * *$ & $0.9802 * *$ \\
\hline Site 5 & $0.8800 * *$ & $0.9233 * *$ & $0.9889 * *$ \\
\hline Site 6 & $0.8806^{* *}$ & $0.8395 * *$ & $0.9878 * *$ \\
\hline Site 7 & $0.5768^{*}$ & $0.6440 * *$ & $0.9626^{* *}$ \\
\hline
\end{tabular}

i) ** Significant at $0.1 \%$ level $(\mathrm{P}<0.001)$, ii) * significant at $1 \%$ level $(\mathrm{P}<0.01)$ 


\subsection{Seasonal Variation of Total Coliform Bacteria and Its Impact on Water Quality}

The Seasonal variations of number of total coliform bacteria (Number/100 mL) in the water samples collected from the seven sampling sites of Mirik Lake during the first and second year of study period are presented in the Figure 3 . During the first year of study the total coliform density varied between 1003 to $54000 / 100 \mathrm{~mL}$. The highest MPN value of total coliform bacteria was found in summer from the Site 2 and the lowest value of MPN was recorded from Site 5 during winter. The maximum MPN value was recorded at the Site $1(88667 / 100 \mathrm{~mL})$ during monsoon, while the lowest value was found from the Site 7 (725/100 $\mathrm{mL}$ ) in the winter season during the second year of study. The seasonal variation in total coliform density revealed their higher presence during summer and monsoon and the lowest MPN value found in winter. The higher MPN of total coliform during summer may be due to the higher temperature which helped bacteria to grow in number. The peak coliforms numbers were observed during summer might also be due to lean discharge of water and higher concentration of drain effluents discharged into the lake. The maximum number of total coliforms was detected during monsoon season might be due to wash-out of fecal matter and over flowing of sewage drains by rain water. The highest total coliform density was recorded during monsoon may be attributed to the runoff during rainfall, which is a major factor in the loading of fecal materials mainly of bovine and human origin into the lake [28].The lower MPN values of total coliform bacteria were found in winter may be due to the lower temperature in the winter which prevents the growth of total coliform bacteria.

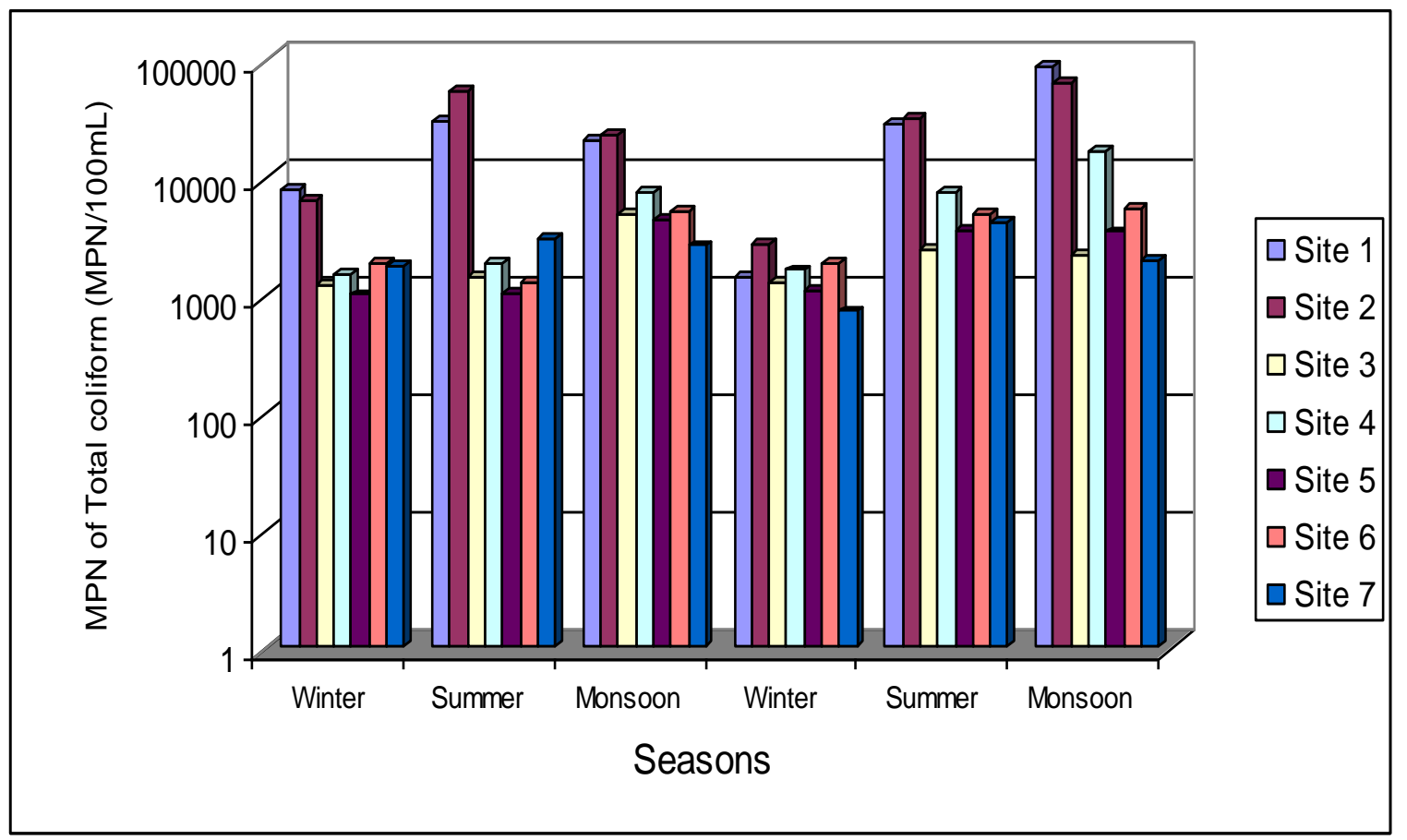

Figure 3. Seasonal variations of Total coliform bacteria of surface water from seven sampling sites of Mirik Lake during thewhole study period (two years). 
According to the "Designated Best -Use water quality Criteria" [41] the limit of number of total coliforms is $500 / 100 \mathrm{~mL}$ for "Class-B" type water (Table 2). From the monitoring data it was observed that, most of the sites the total coliforms numbers were more than the required limit. The total coliform also had positive and significant correlation with heterotrophic bacterial density at all the sites (Table 3).

\subsection{Seasonal Variation of Heterotrophic Bacteria and Its Impact on Water Quality}

The total heterotrophic bacteria include all the bacteria which utilize organic carbon as their major source of energy.

Figure 4 represents the seasonal variations of heterotrophic bacterial density (Number/ $\mathrm{mL}$ ) in the water samples collected from all the seven sampling sites of Mirik Lake. The seasonal heterotrophic bacterial density of surface water of Mirik Lake varied from 1350/ml to $63500 / \mathrm{ml}$ during the first year of study period. The maximum density was observed in summer from Site 2 and the minimum was recorded in winter from Site 7. During the second year of study the highest HPC value was observed in the Site $1(116667 / \mathrm{mL})$ in the monsoon season and the lowest seasonal value recorded in the winter $(1265 / \mathrm{mL})$ from the Site 7 . The HPC values often exceeded the drinking water standard limits (Bureau of Indian Standards) in Mirik Lake. The relatively higher density of heterotrophic bacteria at Site 1 and Site 2 may be due to the sewage input in these sites. Similar observations were reported by Bharathi et. al. [42] in the Ennore coastal waters of India. In the present study a significant correlation between fecal coliform and total coliform bacteria with heterotrophic bacteria were observed (Table 3). Amanidaz et al., [43] also found significant correlation between coliform bacteria with heterotrophic bacteria in water supply networks in Iran.

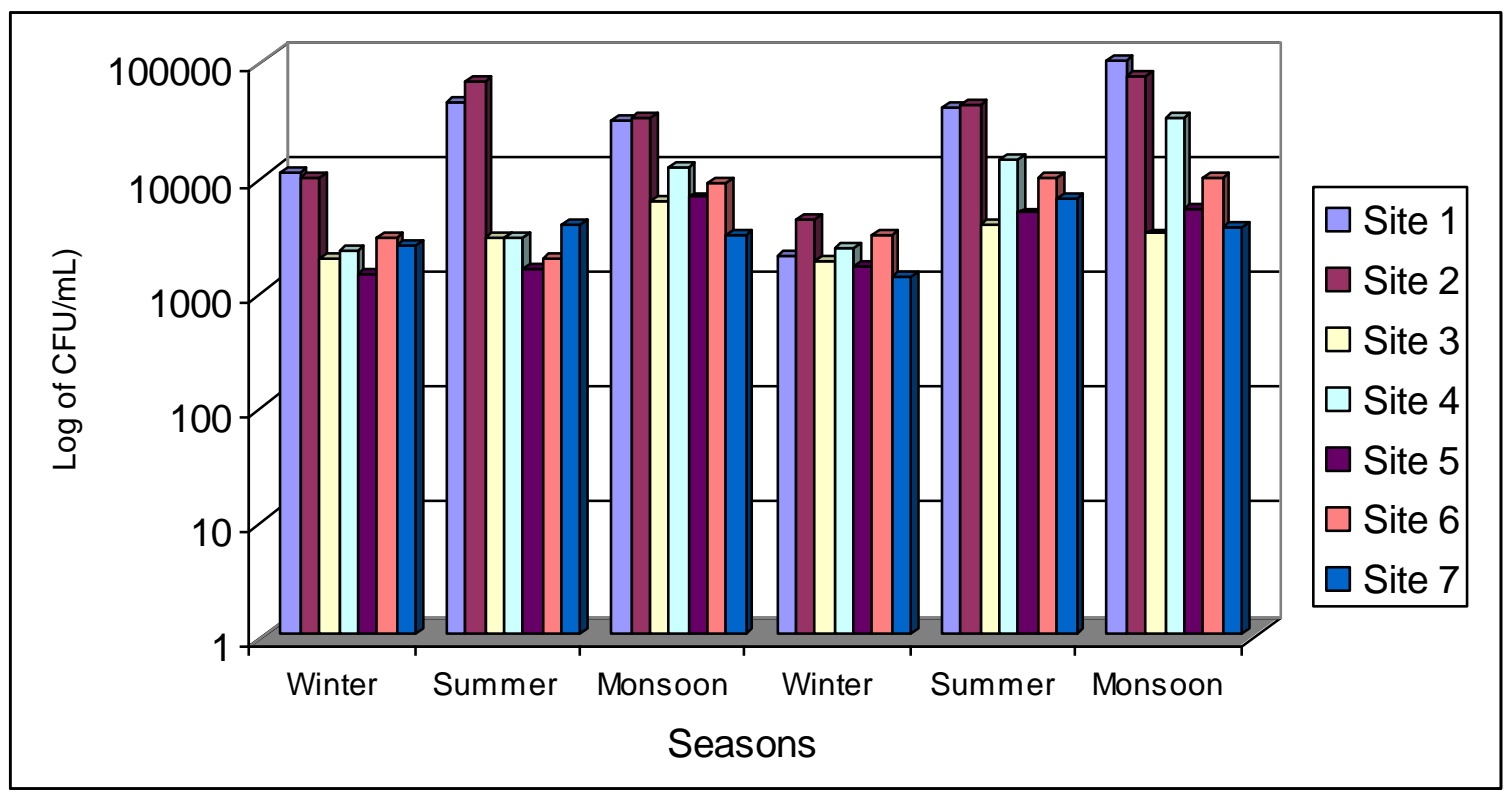

Figure 4. Seasonal variations of Heterotrophic bacteria of surface water from seven sampling sites of Mirik Lake during the whole study period (two years) 


\section{Conclusions}

So, from the present investigation it is revealed that the bacterial water quality parameters like fecal coliform, total coliform and heterotrophic bacterial density exceeded the standard limits in Mirik Lake. Therefore, the local people should boil the water of the lake before consumption. It is also observed that the bacterial densities of Site 1, Site 2 and Site 3 appeared to be much higher than the other sites due to entering of sewage and greater anthropogenic activities at these sites. To avoid health hazards sewage water must be treated before disposal into the lake. This study provides baseline information for decision makers and resource planners and would be a useful tool for further ecological monitoring and assessment of this lake.

\section{Acknowledgements}

The author is grateful to the Director, National Environmental Engineering Research Institute (NEERI), Nagpur for providing necessary funds and to the Vice Chancellor, University of North Bengal for providing laboratory facilities in the Department of Zoology for the smooth completion of the work.

\section{REFERENCES}

[1] D. De Zwart, and R.C. Trivedy. Manual on integrated water quality evaluation. Report No. 802023003, Joint Publication of RIVM and Central Pollution Control Board, East Arjun Nagar, Delhi, India, 1994.

[2] S. R. Caropenter, D. Ludwig, and W. A. Brock. Management of eutrophication for lakes subject to potentially irreversible change, Ecol. Appl, Vol. 9, 751-771, 1999.

[3] A.V. Holden. Effects of pesticides on fish. In: C.A. Edward, editor. Environmental pollution by pesticides, PlenumPress, p. 213-253, 1970.

[4] V. Rodrigues, N. Ramaiah, S. Kaktiand D. Samant. Long-term variations in abundance and distribution of sewage pollution indicator and human pathogenic bacteria along the central west coast of India. Ecological Indicators, Vol. 11, No. 2, 318-327, 2011.

[5] APHA. Standard methods for the examination of water and waste water, $21^{\text {st }}$ edition, American Public Health Association, Washington, 2005.

[6] E.E. Goldreich. Sanitary significance of fecal coliform in the environment. Water pollution Control Research Series, Publication WP-20-3. Federal Water Pollution Control Administration, U.S. Department of the Interior, Cincinnati, Ohio, 1966.

[7] F. Orskov and I. Orskov. Enterobacteraceae, In: A.I. Broude, editor. Medical Microbiology and Infectious Diseases, The W.B. Saunders Co., Philadelphia, p. 340-352, 1981.
[8] M.W. LeChevallier, R.J. Seidler and T.M. Evans. Enumeration and characterisation of SPC bacteria in chlorinated and raw water supplies. Appl. Environ. Microbiol., Vol. 40, 922-30, 1980.

[9] R. K.Trivedy, and P. K. Goel. Chemical and biological method for water pollution studies, Environmental Publication, Karad India, 1986.

[10] M.C. Pant, P.K. Gupta, J. Pande, P.C. Sharma and A.P Sharma. Aspects of water pollution in Lake Naini Tal, U.P., India. Environ. Conserv, Vol. 2, 113-117, 1981.

[11] Millipore Corporation. Water Microbiology, Laboratory and field procedures, Bedford, Massachusetts 01730, USA, 1986.

[12] V. R. Prakasam and M. L. Joseph. Water quality of Sasthamcotta lake, Kerala (India) in relation to primary productivity and pollution from anthropogenic sources, J. Environ. Biol, Vol. 21, 305- 307, 2000.

[13] A.K. Fokmare, M. Musaddiq and M. Dubey, Bacteriological status of drining water in Akola city of Maharashtra. Asian J. Microbiol. Biotech. Env. Sc., Vol.4, 255-258, 2002.

[14] B., Bhadra, R. Chakraborty, S. Das, and A. K. Nanda, Investigation of some basic water quality parameters of the north Bengal Terai river Kaljani- a tributary of river Torsa, and comparision thereof with the mainstream, J. Environ. Biol., Vol. 26, 277-286, 2005.

[15] Isobe, K.O., Tarao. M., Chiem, N.H., Minh, L.Y. and Taada, H. Effect of environmental factors on the relationship between concentrations of Coprostanol and fecal indicator bacteria in tropical (Mekong Delta) and Temperate (Tokyo) freshwaters, Appl. Environ. Microbiol. Vol. 70, 814-821, 2004.

[16] Karagul, R., Samandar, A., Yilmaz, M., Altun, L. and Gedikli, R. Evaluating the seasonal changes of some water quality parameters of the Buyuk Melen River Basin (Duzce, Turkey), J. Environ. Biol., 26, 179-185, 2005.

[17] Jadhav, A.R. and Desmukh, A.M. Physico-Chemical and Microbial Characteristics of Rankala and Kalamba Lakes of Kolhapur district of Maharashtra, Environment and Ecology, Vol. 24, 21-27, 2006.

[18] Usha, R., Ramalingam, K. and Bharati Rajan, U.D Freshwater Lakes- A potential source for aquaculture activities- A model study on Perumal lake, Cuddalore, Tamil Nadu, J. Environ. Biol., Vol. 27, 713-722, 2006.

[19] Ksoll, W. B, Ishii, S., Sadowsky, M. J. and Hicks, R. E.. Presence and sources of fecal coliform bacteria in epilithic periphyton communities of Lake Superior, Appl. Environ. Microbiol. Vol. 73, 3771-3778, 2007.

[20] Radha Krishnan, R., Dharmaraj, K. and Kumari, B.D.R. A comparative study on the physicochemical and bacterial analysis of drinking, borewell and sewage water in the three different places of Sivakasi, J. Environ. Biol., 2007.Vol. 28, 105-108, 2007.

[21] Omezuruike, O.I., Damilola, A.O., Adeola, O.T., Fajobi, E.A. and Shittu, O.B. Microbiological and physico-chemical analysis of different water samples used for domestic purposes in Abeouta and Ojota, Lagos State, Nigeria, African J. Biotech., Vol. 7, 617-621, 2008. 
[22] Rodrigue, G., Teresa, C. and Bastardo, J.W. Investigation of enterobacteria in gastrointestinal contents of the Coroco, Orthopristis rubber (Pisces, Perciformics, Pomadasyidae), Biol. Inst. Oceanogr. Univ. Orientre Cumana, Vol. 14, 140-149, 1977.

[23] Henne, K., Kahlisch, L., Hofle, M.G. and Brettar, I. Seasonal dynamics of bacterial community structure and composition in cold and hot drinking water derived from surface water reservoirs. Water Res., Vol. 47, 5614-5630, 2013.

[24] Patel, V., Munot, H. Shouche, Y.S., Madamwar, D. Response of bacterial community structure to seasonal fluctuation and anthropogenic pollution on coastal water of Alang-Sosiya ship breaking yard, Bhavnagar, India. BioResource Tech., Vol. 161, 62-70, 2014.

[25] Fadaei, A. A Comparison of the Bacteriological Quality of Drinking Water for the Rural of Hooreh and Arjnk, Iran, Resources and Environment, Vol. 4, No. 5,215-219, 2014.

[26] C. Kademane, M. Rajesh, K. M. Rajesh2 and K. Vandana, Studies on Heterotrophic Bacteria and Total Coliforms in Relation with Environmental Parameters of Water in Gurupur Estuary, Off Mangaluru, Karnataka, India, Poll. Res., Vol. 37 No. 4, 989-995, 2018.

[27] M.A. Haque, M. A. Sayed Jewel, M. P. Sultana. Assessment of physicochemical and bacteriological parameters in surface water of Padma River, Bangladesh, Applied Water Science, Vol.9, No. 10, 1-8, 2019.

[28] D. Mondal, J. Pal, T.K. Ghosh, and A.K. Biswas. Fecal coliform, total coliform and heterotrophic bacterial analysis of water of Mirik Lake in Darjeeling hills, NBU J. Anim. Sc., Vol. 1, 99-103, 2007.

[29] D. Mondal, J. Pal, T.K. Ghosh, and A.K. Biswas. Biological monitoring of water quality of Mirik lake in the Darjeeling Himalaya on the basis of algal communities, In: L. Kosygin, editor. Wetlands of North East India: Ecology, Aquatic Bioresources and Conservation. Akanksha Publishers, New Delhi, p. 86-94, 2009.

[30] D. Mondal, J. Pal, T.K. Ghosh, and A.K. Biswas. Abiotic characteristics of Mirik Lake water in the hills of Darjeeling, West Bengal, India, Advances in Applied Science Research, Vol. 3, No. 3, 1335-1345, 2012.

[31] D. Mondal, J. Pal, T.K. Ghosh, and A.K. Biswas. Diversity of Cladocerans and Copepods Mirik Lake in Darjeeling Himalaya, Journal of Today's Biological Sciences: Research \& Review, Vol. 2, No. 1, 36-46, 2013.
[32] D. Mondal, J.Pal. Diversity of Cyanophyceae in the Mirik Lake of Darjeeling Himalaya, India, International Journal of Science and Research, Vol. 3, No. 12,2080-2083, 2014.

[33] U. Dwivedi, Over the hill: Lake pollution in Mirik. The Statesman (NB plus), August 14, Calcutta. 4p. 1998.

[34] C. Berry, B. J. Lioyd, and J. S. Colbourne. Effect of heat shock on recovery of Escherichia coli from drinking water, Water Sci Technol., Vol. 24, 85-88, 1991.

[35] J.C. Geldenhuys and P.D. Pretorius. The occurrence of enteric viruses in polluted water, correlation to indicator organisms and factors influencing their numbers, Water Sci. Technol., Vol. 21, 105, 1989.

[36] W. Burkhardt, III. Calci, K. R., Watkins, W. D., Rippey, S. R. and S. J. Chirtel. Inactivation of indicator microorganisms in estuarine waters, Water Res., Vol. 34, 2207-2214, 2000.

[37] M.Pommepuy, J.F. Guillaud, E. Dupray, A. Derrien, F. Le Guyader and M. Cormier, Enteric bacteria survival factors, Water Sci. Technol., Vol. 25, 93-103, 1992.

[38] C. Crabill, R. Donald, J. Snneling, R. Foust and G. Southam, The impact of sediment fecal coliform reservoirs on seasonal water quality in Oak Creek, Arizona, Water. Res., Vol. 33, 2163-2171, 1999.

[39] T. Kistemann, T. Clasen, C. Koch, F. Dangendrof, R. Fischeder, J. Gebel, V. Vacata, and M. Exner, Microbial load of drinking water reservoir tributaries during extreme rainfall and runoff., Appl. Environ. Microbiol., Vol. 68, 2188-2197, 2002.

[40] WHO (World Health Organization), Water quality: Guidelines, standards and health, IWA Publishing, London, 2001.

[41] CPCB (Central Pollution Control Board), Water Quality in India, Status and trend (1990-2001), New Delhi, MINARS/ 20/2001-2002 pp., 2003.

[42] M.D. Bharathai, S. Sundaramoorthi, S. Patra, T. Madeswaran and A. Sundaramanickam, Seasonal and spatial distribution of heterotrophic bacteria in relation to physico-chemical properties along Ennore coastal waters, Indian Journal of Geo Marine Science, Vol. 47, No. 3, 587-597, 2018.

[43] N. Amanidaz, A. Zafarzadeh, A. H. Mahvi,The Interaction between Heterotrophic Bacteria and Coliform, Fecal Coliform, Fecal Streptococci Bacteria in the Water Supply Networks, Iran J Public Health, Vol. 44, No.12, 1685-1692,2015. 